\title{
The Schism in the Bulgarian Orthodox Church
}

\author{
JANICE BROUN
}

I visited Bulgaria in autumn 1990 and in September to October 1992 and interviewed a number of people, some of whom would prefer to remain anonymous, about the schism. Often their views and information about specific participants were contradictory. As yet, members of the Holy Synod have been unwilling to admit what compromises they made or were forced to make between 1944 and 1989 . When and if Synodical and Interior Ministry documentation is made available it may be possible to get more inside information, but it will probably never be possible to recover the full truth. I would like to thank Spas Raikin, formerly Professor of East Stroudsburg University, for his invaluable help: especially useful was his analysis of the canonical background of the schism in his Open Letter to President Zhelyu Zhelev, 6 August 1992.

\section{The Church under Communism}

When the communists seized power on 9 September 1944, two-thirds of Bulgarians were still nominally Orthodox, but they were perhaps the least religious nation in Europe. ${ }^{1}$ The Bulgarian Orthodox Church had for various social and historical reasons lost much of its real influence and was not equipped to withstand the onslaught of a ruthless atheist government. ${ }^{2}$ The communists launched a policy of terrorism, liquidating 70 Orthodox priests along with other community leaders soon after taking power. Two leading metropolitans, one of whom was Kiril of Plovdiv, the future Patriarch, were tortured. Generally the higher clergy offered less resistance than did the politicians. Communist policy at this stage was to control the church by intimidation rather than by infiltration.

The exarchate bylaws of 1895 had guaranteed the church autonomy. The 1947 Bulgarian Constitution guaranteed separation of church and state. These provisions were, however, rendered void by the Law on Faiths of February 1949, which gave the state almost complete control over the churches. Article 12 required that all clergy be approved by the Committee for the Affairs of the Bulgarian Orthodox Church and of Religious Cults. This was a Department of the Foreign Ministry, which had traditionally handled the affairs of religious bodies in Bulgaria since the substantial ethnic minorities in Bulgaria had links abroad. Should leaders of the respective denominations fail to carry out disciplinary action as required by the Committee, clergy could still be removed by administrative means. In practice, the Holy Synod disciplined its priests without apparent demur.

The church was ordered to draw up new bylaws which had to be submitted to the Foreign Ministry. These gave the bishops the final say on administrative and judicial matters within their own dioceses and enabled the Synod to police the church and 
enforce government dictates. ${ }^{3}$ The bylaws also extended participation in church government to the lesser clergy and the laity. Elected parish councils provided representatives to elect district delegates. These chose the metropolitans (bishops with dioceses, in addition to titular bishops) and the patriarchal electoral college when the Patriarchate became vacant. This process was not as democratic as it might appear since it opened the way for government interference in the selection of parish councils and thus the manipulation of all other elections.

The Tsurkovno-naroden Subor (Council of Church and Nation) was to be elected and meet every four years to decide on the most important questions of church life; but after Kiril's election in 1953 it was not convened again. The church reverted to old canonical procedures whereby the episcopate formalised elections in accordance with the dictates of the government.

In 1971, when Metropolitan Maksim of Lovech became Patriarch, three metropolitans - the leader of the present schism, Pimen of Nevrokop, with Paisi of Vratsa and Iosif of Varna (both now deceased) - signed an Exception to the Synod's decision. They rejected the majority choice of Maksim on the grounds that it did not conform to the provisions of the 1951 bylaws. Ignoring canon law, which vests church government in the episcopate as inheritors of the apostolic succession, the metropolitans argued that the fundamental authority lay with the parish councils. The Patriarch, in their view, represented the apex of an electoral pyramid. Their very argument, however, contravened canon law, which takes precedence when there is any ambiguity or where state law and canon law are at variance. ${ }^{4}$

The state exploited the poverty of the church in order to tighten its grip. The church's financial resources and estates were so limited that ever since its declaration of autocephaly it had been dependent on state subsidies. Under communism its main source of income was the sale of candles. The state subsidy, 13 per cent of its income, just covered its annual deficit. Despite its legal recognition (Article 3 of the Law on Faiths) as the traditional religious denomination of the Bulgarian people, and the fact that it was allowed institutions denied to other churches and religions, the Orthodox Church led a narrowly circumscribed existence. Its publishing activities were very limited and the Synod bookshop virtually empty. Only one (badly printed) edition of the Bible appeared, in 1982, and most of the 28,000 copies ended up locked away in monasteries. ${ }^{5}$ No religious instruction of children under 16 was permitted. In 1962 the government boasted of a dramatic decline in church membership unmatched elsewhere in the Soviet bloc.

By the early 1970s, however, it was obvious to the government that the church was not dying out. The government accordingly adopted a policy of infiltration on a massive scale, in order completely to atheise the church from within. This policy largely succeeded, according to some observers, though it took time. ${ }^{6}$ The Patriarchs Kiril and Maksim and the older metropolitans had been chosen from among genuine monks. As the older generation of bishops gradually died off, however, they were replaced by men who were susceptible to persuasion to cooperate with the state, either in return for favours or because they had been compromised. All theological institutions except two were closed. One survivor, the St Kliment of Okhrid Academy in Sofia, was withdrawn from Sofia University, closed to women and for the next 20 years filled mainly with university rejects. These furnished a recruiting ground for agents of the security services, who were then expected to make a career in the church. Security agents were appointed to some staff posts and helped to shield young agents during their studies. The other institution to survive, the Seminary in Sofia, was moved out to the Cherepish monastery. Candidates were deterred from joining and 
discrimination was practised against their famiies. Infiltration proved less successful here because the students were younger - entry was at age 13.

The numerus clausus, abnormal conditions, pressure of various kinds and the normal processes of attrition reduced the number of priests from 2446 for some 2200 churches in 1948 to around 1500 in 1983, of whom 500 were already retired. Priests were often responsible for several churches, and pastoral care was badly affected. Many priests were visibly mercenary; some behaved in a way that made it clear that they were unbelievers.

Possibly some members of the Synod were too. Some observers have written all the bishops off as security colonels in cassocks. The truth is more complex, however. Some compromise was necessary for the church to survive. How far it should have gone is the real point at issue. Certainly Patriarch Maksim himself and many of the bishops have served the state loyally, even obsequiously, especially in promoting a favourable image of communist Bulgaria to foreigners through the World Council of Churches and Christian Peace Conference. There is no record of any dissent within the Synod or of any Synod complaints to the authorities about discrimination against believers, intensive anti-religious propaganda and education in schools or substitute secular rites of passage. The Synod became completely discredited among the faithful.

\section{The Synod Resists Reform}

Belatedly, in 1988 and 1989, a number of human rights initiatives surfaced in Bulgaria, including an 'Independent Committee for the Defence of Religious Rights, Freedom of Conscience and Spiritual Values', Orthodox in composition. The Synod showed no enthusiasm for this Committee, and on $28 \mathrm{March} 1989$ categorically denounced it, thus enabling the state to refuse to register it. ${ }^{7}$

The Synod had already twice disciplined the Committee's leading member, Hieromonk Khristofor Subev. He was exiled to Cherepish for organising processions in his parish in Veliko Turnovo. Subev came from a communist party background (though he did not publicly admit this until autumn 1992); his father worked in Ministry of the Interior prisons. As an activist student he had led a group of Che Guevara sympathisers. As an atomic physicist he was allowed to study in Moscow. Following two broken marriages he took monastic vows in 1980 , enrolling in an Academy correspondence course. One of his teachers at that time suspected him of being an agent of the security services. ${ }^{8}$

In 1989 he emerged as a leading dissident. His interesting and constructive ideas won widespread approval among people who belonged to the church and the many more who were sympathetic and looked for a reformed church to provide a moral lead as Bulgaria emerged from communism.

Subev's Committee campaigned to end state interference in religion. It also aimed to promote understanding and tolerance among the different faiths of Bulgaria, Judaism and Islam included. It supported the Turks who were under threat of complete forcible assimilation. Subev was imprisoned during the summer of 1989 because of his campaign on their behalf. At the same time, the Synod was publicly affirming the status quo, and gratefully acknowledging its mutually respectful relations with the state. It spoke of 'planned and systematic Scripture publishing' and of the church's 'evangelisation of her spiritual children'. Such patently false claims only brought it into deeper disrepute. ${ }^{9}$ Subev and the Committee participated in the events of 10 November which precipitated the fall of Zhivkov, and in the subsequent 
round table discussions with the government on democratisation. Nine independent groups coalesced to form the Union of Democratic Forces (UDF). While Subev pressed for religious renewal and reform and for Maksim's resignation, the Synod, relegated to observer status, waited to see which way the wind would blow. ${ }^{10}$

When on 9 January 1990 the Synod summoned up courage to broach the question of normalisation of church life with the government, it appropriated the Religious Rights Committee's programme, which it had previously condemned, and presented it as its own. There were a few tactical omissions, such as the requests which would require changes in the Constitution, and appeals for greater cooperation between different denominations and religions. On the question of ecumenism, Subev remained far ahead of his establishment. ${ }^{11}$

\section{The Synod under Pressure: the Transition Period after the Revolution}

Until October 1991 the government was still dominated by communists. The first free elections in June 1990 were won by the Bulgarian Socialist Party (BSP), the revamped Communist Party. The Synod did not distance itself from the government; Metropolitan Pankrati of Stara Zagora, who as head of the Synod's Foreign Department had been a most effective government propagandist, was elected to the National Assembly for the Fatherland Union, a BSP front party. ${ }^{12}$

In order to counter the UDF's commitment to religious reform, the government adopted a reformist image, and government representatives put in appearances at national religious services. It tried to recruit Orthodox support, particularly in regions with large Turkish minorities, where it encouraged anti-Turkish demonstrations among a chauvinist right-wing Orthodox element.

Church life was gradually resumed on a more normal basis. ${ }^{13}$ Thousands who had not dared to enter a church now tiptoed in to light candles or queue for rites of passage. The 'kairos' had arrived, but the church, crippled and corrupt as it was, could not meet the challenge. The Synod authorised the printing of 300,000 Bibles, $^{14}$ but this edition fell short of Subev's demand for a Bible in every home; even by October 1992 many boys at Plovdiv seminary, reopened in 1990, had not been able to get hold of one. Cherepish Seminary was relocated in Sofia. The Academy readmitted women. But it was the Religious Rights Committee, backed by the UDF, which kept up pressure for the extension of religious activity, optional teaching of religion in schools and local government provision of sites for churches in all new housing estates. ${ }^{15}$

The Synod announced it would convene a Subor in 1990, and unexpectedly nominated Subev to the preparatory commission. ${ }^{16}$ It then apparently had second thoughts, perhaps fearing the embarrassing public accusations and revelations which might emerge. The Subor did not take place.

On 1 January 1991 Dimitur Popov's BSP government responded to the Committee's request for the replacement of the Foreign Ministry's Committee for Religion by a supervisory Board for Religious Affairs, ostensibly to act as an interim body until problems left over from four decades of repression were resolved. To many believers the new Board looked suspiciously like the old Committee in new clothes. Although Article 13 of the new Constitution of 12 July 1991 emphasised that religious denominations are free and separate from the state, the Board insisted that all religious bodies and their leaders be registered and that their statutes be congruent with state laws. ${ }^{17}$ Article 13 also affirmed that 'the traditional religion in the Bulgarian Republic is the Orthodox faith', and proved so controversial that the 
National Assembly spent a day discussing it. Leaders of other religious bodies feared that this Article might be used to justify discrimination against them. ${ }^{18}$ In the event their fears proved groundless. It was the Orthodox Church which was split by state interference.

In 1990 Professor Radko Poptodorov, an expert in canon law, condemned church leaders for their subservience to the regime, their neglect of the church's canons and their corruption and lust for power. ${ }^{19} \mathrm{He}$ pointed out that the Synod had been run by people who had not been elected in accordance with the church's statutes but appointed by the regime. He complained that for 40 years the Synod had not reported on the state of the church, so that matters which had once been discussed publicly were shrouded in secrecy. He alleged that the Synod had fostered apathy in clergy and lay people and caused moral decay, especially among young people. These 'misdeeds', he argued, provided sufficient grounds for the removal of bishops. According to Poptodorov, although all the bishops had been validly consecrated, since 1951 no proper elections for the Patriarch or for the metropolitans had been held. Electors had been deprived of their canonical rights. Since the mandate of the last Subor had expired in 1954, all appointments of metropolitans had been at the direction of the state and were therefore invalid, including that of Maksim as Metropolitan of Lovech in 1960; his election as Patriarch in 1971 was also invalid. The last surviving metropolitan to be canonically elected had been Pimen of Nevrokop in 1952 . Poptodorov was to become the leading ideologist of Subev's group.

On 7 July 1990 the Synod publicly admitted its guilt 'for some activities'. On 20 July Metropolitans Pimen of Nevrokop, Pankrati of Stara Zagora, Stefan of Veliko Turnovo, Kalinik of Vratsa, Dometian of Vidin and Kiril of Varna and Preslav caused a nationwide sensation when they issued a public repentance. Not everyone was convinced that the penitents were genuine; Subev, who claimed that the Synod consisted entirely of communists, commented that God was knocking at the doors of their souls. ${ }^{20}$

In 1991 Dr Boris Miloshev, head of the Movement for the Renewal of the Bulgarian Orthodox Church, demanded that the Synod name the clergy in whose persecution, and even death, it had been implicated, and that it reimburse the money squandered on ecclesiastical feasting and entertainment and suspend work on the luxurious new Synod summer residence in Varna as inappropriate for monks. ${ }^{21}$

In 1991 Metodi Spasov, the head of the new Board for Religious Affairs, raised with the Patriarch the question of calling a Subor, and they agreed that preliminaries would start after the October elections.

From July 1990 until May 1991 Subev was also a vice-president of the UDF's Coordinating Committee. Some people who had supported Subev were beginning to have reservations about what they saw as his commitment to politics at the expense of church renewal. Some disapproved of his monarchism: the Bulgarian monarchy is German in origin, dates back only to the nineteenth century and evokes little enthusiasm among most of the population. Many were disturbed by the increasingly confrontational public demonstrations he organised. In all, Subev's activities were causing increasing polarisation within church ranks.

Subev used outdoor rallies, candlelit vigils and processions as a vivid means of publicity, especially for those who, while not being committed Christians, were sympathetic towards a revivified national church. Sofia University students, who in June 1990 were involved in a gruelling month-long sit-in under the threat of Mladenov's tanks, recall with gratitude how he brought them oils for baptism. When, however, he mounted a concert on Easter Eve, which attracted 50,000 people but 
which clashed with the major Orthodox service of the year, some questioned the authenticity of his faith. In May 1991, he and his followers took advantage of the visit of Ecumenical Patriarch Dimitrios to Sofia to make public demands for Maksim's resignation and mock him as 'Zhivkov's protégé'. Poptodorov for one was not happy about the demonstration and commented sadly that it was easier to topple dictators than to get rid of members of the church hierarchy. ${ }^{22}$

Few church members had any illusions about Maksim, now 77, and reputed to have been chosen by the government for his mediocrity and submissiveness. Critics like the young Balkan media editor Rossen Milev say that he should have retired gracefully to a monastery - there were precedents in Bulgarian history. Some suspect that he is a party member, an agent and an atheist; a reliable informant says he is none of these, but accuses him of cowardice and inertia, and says that if Maksim had not been prepared to give a satisfactory account of his past and apologise for his mistakes, he should have resigned. However, Maksim has a stubborn streak. Meanwhile scandals continued to occur. In the winter of 1990-1, when the whole country was on the verge of collapse, aid from Switzerland and Greece, including 50 beds for a hospital, allegedly got no further than the Synod and its employees. ${ }^{23}$

\section{The UDF Government Loses Patience with the Synod}

In October 1991, 67 per cent of Bulgarian electors voted against the BSP. Nevertheless, the UDF's majority was so narrow - $\mathbf{3 4 . 3 6}$ per cent against the BSP's 33.14 per cent - that it had to depend largely on the goodwill of its ally in bringing about the downfall of Zhivkov in 1989, the mainly Turkish Movement For Rights and Freedoms (MRF).

The new government was determined to make a clean break with Bulgaria's communist past, and religious institutions were among its targets. The more radical reformers viewed the Board for Religious Affairs as an appropriate vehicle for purging the Synod and Muslim Supreme Council, which still contained compromised members. The government reacted sympathetically to complaints from frustrated Orthodox and Muslims. Subev blessed the incoming cabinet and young Prime Minister Filip Dimitrov, who claimed to be a practising member of the Orthodox Church. Appointed Chairman of the Assembly Commission on Religious Affairs, Subev filled it with opponents of the establishment. ${ }^{24}$

As a result of inadequate vetting of election candidates the UDF itself was not as uncompromised as it first seemed. People closely connected with the previous regime had infiltrated it. According to some observers, the security service was still intact and interested in fomenting division within the Orthodox Church. The schism which ensued was certainly not a clear-cut matter. The aims of the 'decommunisers' within the church were not incompatible with those of the former communist establishment. Complex double games were being played, probably involving blackmail as people posing as UDF activists got access to the Synod's files. ${ }^{25}$

The Board for Religious Affairs demanded that both Patriarch Maksim and selfconfessed former agent Grand Mufti Nedim Gendzhev resign. When both refused, the Board insisted that the Synod and the Muslim Supreme Council both apply for formal registration, just as other denominations had done. Since there was no response, the Board resorted to drastic steps. On 21 February 1992 it appointed a new acting Grand Mufti, announced the suspension of the Muslim Council and ordered it to vacate the Grand Mufti's office. Gendzhev and the Council sat tight. ${ }^{26}$

The Synod and Muslim Council called first on the judiciary to arbitrate and then on 
the Supreme Court to repeal the Board's ruling against them; but without success. Meanwhile Subev had been busy on another tack. On 18 March Metropolitans Pimen of Nevrokop, Pankrati of Stara Zagora, Kalinik of Vratsa and Stefan of Veliko Turnovo suddenly changed sides. They presented Maksim with a signed statement: 'We... testify in our hierarchs' conscience that the violation of the bylaws in Maksim's election for the Patriarchate in 1971 renders his service illegitimate and should be terminated.' ${ }^{27}$ On 15 May Prime Minister Dimitrov, who since 1989 had been involved as a lawyer with amending the 1949 Law on Faiths, declared himself opposed to state interference in religious affairs. He said that many of the amendments to the Law revealed a deep ignorance of canon law and could be used against the interests of religious believers if the state so intended. ${ }^{28}$

When the dissident metropolitans failed to appear at the Synod meeting on 19 May the Synod realised what was afoot and briefed President Zhelyu Zhelev. Zhelev, who had already requested the Constitutional Court to consider the legality of the Board's policies, confirmed his decision that the state should not intervene. ${ }^{29}$

It was now public knowledge that Orthodox and Muslim leaders had been directly appointed by Zhivkov's government. On 18 May five metropolitans elected Pimen of Nevrokop as new acting head of the Synod. On 26 May Spasov ruled Maksim's election invalid.

\section{The Schism}

Backed by a written endorsement from the Board for Religious Affairs, on 19 May 1992 Metropolitan Pimen of Nevrokop and his fellow rebels announced the creation of a new Synod purged of tainted bishops, declared Maksim's election invalid and elected Pimen as its head. One metropolitan and five other bishops joined it. On the same day they made Subev an archimandrite.

On 25 May, Spasov declared Maksim and the entire Holy Synod uncanonical. He justified his action by means of the 1949 Law on Faiths and the Synod's failure to register, arguing it could no longer represent the church. The Board authorised Pimen's group as a new Provisional Synod with a mandate to convene a national Subor as soon as possible. The Council of Ministers concurred with its decision on 1 June. The old Synod (henceforth the 'Synod', as opposed to the 'Provisional Synod'), was given no opportunity to query procedural irregularities or to defend itself.

At Blagoevgrad on 26 May the Provisional Synod defiantly consecrated Subev Bishop of Makariopol in violation of Orthodox canons, which stipulate that an episcopal consecration must have the assent of all the bishops to be valid and which forbid clergy to be involved in politics. The choice of Makariopol was tendentious because it lies in what is now (Yugoslav) Macedonia. The Provisional Synod later revived other eparchies: Silistra, Samokov and Burgas.

The Provisional Synod was by now losing support, however. Metropolitan Sofroni of Ruse and Bishops Nestor, Naum and Ilarion had second thoughts and withdrew, leaving four metropolitans, two bishops and one invalid bishop. ${ }^{30}$

On 31 May Subev and a group of supporters occupied the Synod building on behalf of the Provisional Synod and erected barricades behind the door. The Procurator and police refused to intervene. Spasov later apologised for Subev's preemptive action, explaining that the Board had been preparing legal means for the occupation. On 1 June the Provisional Synod pledged to press for the correction of remaining injustices, including the restoration of Sofia's St Alexander Nevsky Cathedral and 
St George's Church and of Rila Monastery - still a state museum - to church ownership and the restoration of St Kliment of Okhrid Academy to Sofia University. It demanded that religion be restored as an optional school subject. ${ }^{31}$ Spasov blamed the old Synod's inactivity for the fact that the way was now open for churches and sects from abroad, many of them controversial, to make a breakthrough in Bulgaria. $\mathrm{He}$ also claimed that even the Foreign Affairs Committee had not dared to register Maksim's election in 1971, despite their being asked to do so. He accused some old Synod members of being Security collaborators, identifying Synod Secretary Neofit of Levka, on record in the Sixth Department of State Security as a collaborator. Neofit, in defence, argued that the church had to minister to communists who were 'religious at heart but too afraid to show it'. ${ }^{32}$

\section{A Tainted Provisional Synod}

The state's foray into the internal affairs of the church appalled many who, whatever their reservations regarding the Patriarch, regarded this as a violation unprecedented in Bulgarian history. Critics, including sections of the press, expressed their view that the Provisional Synod was a vehicle of power for a compromised minority clique and that Subev was an opportunist, an ambitious adventurer with an eye on the Patriarchate. A radical minority approved of the developments, maintaining that reform was impossible as long as the Patriarch and Holy Synod were intact. Rossen Milev, for instance, argued that the morality of the church is more important than its unity, and that unity is a hangover from the communist past. The fact remains that the state's intervention and connivance with the use of force split the church; and the subsequent actions of both sides further discredited it.

That the Chairman of the Assembly Commission on Religious Affairs should have engineered a schismatic synod was, to say the least, an anomaly. Not even under the communists had the church been subjected to such an irregularity. The composition of the Provisional Synod strained credibility. The leading proponent of radical purge, Subev, had entered into alliance with the three metropolitans who were generally regarded as the most compromised, and whom he had castigated publicly in Demokratsiya.

Together with Maksim, these three metropolitans had for 20 years constituted the Synod Standing Committee, and had thus jointly presided over the Synod's growing disrepute. According to church canons, the metropolitan members of the Synod had to stand for reelection every four years. Pankrati and Kalinik had just been asked by the Synod to resign. ${ }^{33}$

Spas Raikin had been critical of these metropolitans for years. In his surveys of the church and his open letter to President Zhelyu Zhelev ${ }^{34}$ he pointed out that in the early 1950s the Synod had refused to elect Pimen of Nevrokop for two years because they suspected he was a security officer. Raikin rated him as 'unequalled in his servility - including a panegyric on Stalin'. Raikin blamed Pimen for the arrest and disappearance for several years of Sofia diocesan official Archimandrite Miron, and accused him of expelling the best priests from Bulgarian parishes in the USA during his visit there in 1963. In Raikin's view Pimen had already shown his ambition when he challenged Maksim's election. In the church's Foreign Department Pankrati of Stara Zagora had continuously denied persecution of the church. $\mathrm{He}$ is, however, described by a reliable informant as 'a good man, crushed into working for the security, not an agent or an atheist'. Another observer is of the opinion that his conscience was catching up on him. Kalinik of Vratsa is popularly known as the 'Red 
Bishop'. In early May 1992 it was alleged in the newspaper Demokratsiya that he was uncanonically elected under pressure from local communist leaders in 1974, that he collaborated with the security services, carried a gun and was involved in repression of clergy who challenged the Synod. A reliable informant has told me that he was not in the security service, nor was he an atheist, but that he did collaborate.

\section{The Synod Fights Back}

Patriarch Maksim and his Synod, seven metropolitans and eleven bishops, petitioned Zhelev. In response, the President condemned the intervention of the Board for Religious Affairs as scandalous and asked the Constitutional Court to address the question of separation of church and state and the role of the Board. On 11 June the Court ruled that Article 12 of the 1949 Law on Faiths, under which the Board was acting, was unconstitutional, but left it for the Supreme Court to decide which was the legitimate Synod. ${ }^{35}$ On 2 July the Supreme Court rejected the Synod's petition on a technicality. It had missed the Board's deadline for registration by one day. ${ }^{36}$

The Provisional Synod tried to 'reclaim' more property. Pimen requested the Chief Procurator and the Mayor of Sofia to provide armed support to enable it to take over the Sofia diocesan of fice, which had become the Patriarch's temporary headquarters. Though the Mayor registered a Provisional Synod Diocesan Council, and the Procurator openly sided with Pimen, they declined to provide an escort. Pimen ordered Maksim to vacate the premises and retire to Troyan Monastery. He also exiled Bishops Neofit and Natanail (Vicar of Sofia diocese). All these orders were ignored. However, the Provisional Synod managed to evict the Metropolitans of Lovech and Varna and the Vicar of Turnovo from their offices and the monks from Rozhen Monastery. It also tried to occupy Rila Monastery. In Plovdiv it encountered local resistance and failed to evict Metropolitan Arseni. ${ }^{37}$

Subev organised a rally in front of Sofia Cathedral in support of the Provisional Synod on 10 June. Pimen led a human chain to bar Maksim's access to the Cathedral for a special liturgy to commemorate his installation. Thereafter, each night ordinands mounted vigil in shifts behind the iconostasis to protect the Cathedral from capture by Provisional Synod supporters. (Most theological students appear to be opposed to the schism.) On occasion Subev and his supporters interrupted the liturgy, brandishing placards and shouting slogans like 'Maksim is Satan!' or 'Purge the church of communists!' On the whole they did not meet a friendly reception, though church members were divided and could be seen arguing on the steps after services. It did not go unnoticed that among Subev's supporters were men who used to prevent youngsters from going to church before 1990, as well as extreme democrats who had tried to burn down the Assembly in 1989. Bodyguards, armed with sten guns and rubber truncheons, were apparently paid for out of church money. ${ }^{38}$

Maksim's party too included dubious elements who seemed only too eager to resort to violence. Armed with iron bars and a relic of the Holy Cross some tried to reoccupy the Synod building on 12 July. When Subev refused them entry the priests and at least one bishop rolled up their vestments and attacked. They were repulsed with tear gas. The Synod then resorted to ecclesiastical discipline. On 22 July it unfrocked Metropolitans Pimen, Pankrati, Stefan and Kalinik and Bishops Antoni and Galaktion, and excommunicated Subev. The Provisional Synod described the sentences as 'medieval'. 39

Bulgarians avidly followed these confrontations on television and in the press, where scurrilous articles outnumbered pieces of responsible journalism. Most genuine 
church members knew which side they supported, but the general public was confused and tended to dismiss all those involved as communists and give the church a wide berth.

On 30 August President Zhelev accused the coalition government of attacking the unions and independent press and of disrupting the Orthodox Church. When the old Synod pressed Prime Minister Dimitrov, as a 'deeply religious person', to settle the schism, he refused, unless both Synods showed readiness to make concessions. ${ }^{40}$ Since the old Synod refused to talk to excommunicates or their associates ${ }^{4 !}$ and Subev refused to talk to Maksim, the impasse remained. The general consensus was that Zhelev, although an atheist, behaved responsibly, whereas Dimitrov was widely distrusted. On 3 September priests from a self-constituted Movement for the Unity of the Bulgarian Orthodox Church petitioned Dimitrov to evict the Provisional Synod and disband the Board for Religious Affairs. ${ }^{42}$ At the UDF Conference on 22 September one of the topics discussed was the 'decommunisation of the Bulgarian Orthodox Church'.

On 3 June, Spasov froze the Synod's bank account. ${ }^{43}$ As a result, those priests and seminary staff who refused to acknowledge the Provisional Synod went unpaid. Most priests supported the Synod. Generally they found they could just get by on fees for rites of passage. About 200 members of the Priests' Union, under the leadership of Professor Poptodorov, sided with the Provisional Synod. The staff of Plovdiv Academy refused, as their Rector Archimandrite Evlogi put it, to 'sell their consciences'.

The Provisional Synod tried to take over the seminaries at the start of the new academic year. It appointed Poptodorov as Rector of Sofia Seminary. On the night of 31 August its men climbed in with guns in their hands, disarmed the staff, occupied the offices and refused admittance to the Rector, Bishop Grigori. At 2 p.m. on 13 September, while Bishop Grigori delivered a speech at the padlocked gates, 30 students climbed over the back wall and within a few minutes recaptured the building. Church bells were rung to celebrate their victory. Subev complained later of their rough behaviour, and of the fact that the police had not been called in to deal with them. In the course of the scuffle, Poptodorov's arm was broken. ${ }^{44}$

Plovdiv Seminary was not raided but its reopening was delayed by three weeks and its third-year intake dropped from 40 to 35 . Archimandrite Evlogi maintains that it will take years to cure the wounds the schism inflicted in the souls of both staff and boys.

At 8 a.m. on 1 October the Provisional Synod sent a group of officials and a deacon, backed by a warrant from the Chief Procurator, to take over the Sofia diocesan office, Maksim's headquarters. According to Subev they deliberately chose a moment when the building would be empty; but a lady receptionist was manhandled. The telephone wires were cut. Cathedral bells were tolled, members of the National Assembly gathered. Students again rushed to the fray and were met by tear gas; the police had to intervene to protect the Provisional Synod officials, who were ejected. Subev privately blamed President Zhelev for intervening on Maksim's behalf and accused his former close colleague in the dissident movement of betraying their ideals and backing the communists against the church. He lamented that communists still exerted a stranglehold in many spheres, including church affairs. 'Communists buy souls with money, they buy spiritual power too if possible. People do not know whom to believe. They are misled, confused.'45 Milev noted that long experience in government delegations and good links abroad gave Maksim's Synod a tactical and strategic advantage in presenting their case. 
During the autumn the position of the UDF government became increasingly shaky. Neofit, Secretary of the Synod, commented that the government's interference in church affairs was only one factor in its unpopularity, and most of Subev's supporters in the UDF would now vote against the government. ${ }^{46}$ Some church members who had once supported Subev, including Evlogi, now admitted that they wanted the government to collapse and the Board for Religious Affairs to be abolished. Others felt both Synods should go. The UDF, though still determined on Maksim's resignation, had come to regard Subev as a liability. ${ }^{47}$ Its members seem to have realised that, for all their disapproval of certain aspects of the church, it was impossible to establish an alternative church in the way Subev wanted.

The BSP exploited the schism, backing Maksim and his Synod so as to ingratiate itself with church people and facilitate its own return to power. Some of Maksim's supporters pretended not to see the hypocrisy involved in the situation, trying with some success to persuade believers that the West, the Vatican and the freemasons were trying to ruin the church.

On 28 October the Movement for Rights and Freedoms (MRF) withdrew its support and Filip Dimitrov's government fell. The nation was plunged into a crisis while the three major parties bickered. It took two months to resolve, when the parties agreed on the MRF nominee Lyuben Berov, an uncontroversial economist, as Prime Minister. ${ }^{48}$ The new government was essentially one of technocrats. ${ }^{49}$ It represented an uneasy alliance involving the BSP, the MRF and a rebel segment of the disintegrating UDF.

\section{The Demise of the Provisional Synod? 50}

By October the Provisional Synod was showing distinct signs of strain. 'They are eating one another', was Evlogi's comment. Kalinik consecrated as bishop Archimandrite Gennadi, who was an elected municipal councillor for the United Party of Labour, one of the parties in the BSP coalition. Subev resented this consecration, which was done without his approval. Some of Maksim's supporters in Burgas kidnapped Gennadi and held him for two hours before the police rescued him.

On 1 November, two and a half years after first announcing its intention to do so, the Synod organised elections for parish councils as the preliminary towards convening a Subor in spring 1993. Considerable care was taken to ensure that all candidates and electors were genuine church members. Candidates had to be over $\mathbf{3 0}$ years old, regular churchgoers and of good repute. All voters had to produce their baptism certificates made out not less than five years previously plus identity documents to prove they resided in the parish. The considerable interest shown in these elections indicated the importance attached to the Subor as providing the only realistic way to resolve the problems of the church and open the way to genuine renewal. An observer from the St Kliment of Okhrid Academy who had felt unhappy about the many dubious candidates standing in previous state and local elections noted how electors sought his opinion on candidates, asking searching questions about their backgrounds, apparently to ensure that their votes did not go to communists. Since most candidates were sponsored by the UDF, some electors expressed concern that some would be followers of Subev who would press for Maksim's resignation. Later, the Synod challenged the validity of these parish elections. Nevertheless, it went ahead with planning diocesan elections for 24 January 1993. Each diocese contains several districts, each of which elects three clergy and three lay representatives. During their four-year mandate these are to elect diocesan 
electors who will participate in the elections for the Patriarch and metropolitans, the national Subor and the diocesan councils.

Meanwhile, on 6 November 1992 the Constitutional Court ruled both Synods invalid: the old Synod for not observing either state laws or Orthodox canons when it applied for registration, and the Provisional Synod because the Board had no right to register a Synod not elected by church members. The old Synod challenged the Court's decision.

During December Subev left the Synod building, on the grounds that his task was accomplished and his presence there was no longer necessary. He was reported to be seeking reconciliation with the Synod, without success. The Provisional Synod appeared to have no further use for his services. January 1993 saw the Provisional Synod further weakened as the Synod consolidated its position. Prime Minister Berov assured a Synod delegation that his government would do its best to assure the church its proper role in national life.

At the Blessing of the Waters in Sofia Cathedral on 6 January, Berov and other senior government figures were present, as well as (for the first time since 1945) representatives of the army. Also present were Metropolitan Chrysostom of Ephesus and two other top-level delegates from the Ecumenical Patriarchate. On 10 January Chrysostom publicly declared the Patriarchate's support for the Synod, stating that it had not been approached by the Provisional Synod. However, Poptodorov objected to the Ecumenical Patriarch's interference on the grounds that he is only primus inter pares among Orthodox church leaders. The President stressed to the Ecumenical Patriarch his conviction that the renewal of the church can be achieved 'only in accordance with its canons, and without interference (by the state) in church affairs'. The new cabinet pledged to abolish the Board for Religious Affairs.

In the opinion of some observers, the restitution of the Synod, though essential for the church, could enable deeply compromised bishops to take key positions. The manoeuvres of the Provisional Synod have provided the Patriarch and his supporters with an aura of semi-martyrdom among many less critical believers. Simeon of Western Europe, Dometian of Vidin and Kiril of Varnaare three who proved their loyalty to the old regime..$^{51}$ Some of the other bishops have a reasonable reputation; but the systematic corruption of the church all but staunched the flow of genuine vocations and the pitiful decline of monasticism has reduced the pool of suitable episcopal candidates to a handful. The church is in desperate need of fresh pure young blood. Though the boys entering the seminaries look promising, some unsuitable students are still being accepted by the Academy. The power struggle will go on, but it will now be concentrated within the electoral process rather than between two flawed Synods.

Subev continued to be active. On 26 January, in front of television cameras in the church of SS Kiril and Metodi in Plovdiv, he and a Spiritual Tribunal consisting of two prosecuting priests, eleven clergy and three lay people solemnly anathematised communism and all actively associated with it, in imitation of Russian Orthodox Patriarch Tikhon's anathema of communism in 1918.52 They specifically targeted the 'pseudopatriarch' Maksim and his assistants Neofit and Natanail, Vicar of Sofia Diocese, accusing them of betraying the Bulgarian Orthodox Church and excommunicating themselves by permitting Greek Orthodox interference. They also condemned Kalinik and Pankrati and their collaborators of the Provisional Synod for their 'loyal service to communism', castigating them for their failure to fulfil their previous public promises of repentance, especially evidenced by their consecration of a known socialist, Gennadi. Later they excommunicated Maksim and Metropolitans 
Pankrati and Arseni of Plovdiv, as well as their collaborators Neofit, Natanail and Gennadi. They judged the rest of the bishops less guilty, naming almost every single one, including Pimen of Nevrokop, along with the leaders of the Union of Priests and the Movement of Priests for the Unity of the Bulgarian Orthodox Church, but set them all a deadline (10 February) for public repentance.

One commentator on church affairs has suggested that with the exception of glaring cases of collaboration all clergy should be given a chance to prove their commitment to their ministry by diligence and loyalty. He feels that it would be best to delay the election of a new Patriarch until conditions of democracy and openness are fully established. ${ }^{53}$

\section{Notes and References}

1 Spas Raikin, 'The Bulgarian Orthodox Church', in Pedro Ramet (ed.), Eastern Christianity and Politics in the Twentieth Century (Duke University Press, Durham and London, 1988), p. 171.

2 Raikin, op. cit. pp. 160-71. Although the church unilaterally declared itself autocephalous in 1878, with the establishment of an independent Bulgaria, it existed in an ecclesiastical limbo until 1945 when it was recognised by the Ecumenical Patriarchate of Constantinople. The protracted struggle with the Greek bishops for autonomy weakened it considerably. In the early years of independence the bishops' injudicious involvement in political squabbles alienated many of the lower clergy and laity. Antagonism between the church and the imported Germanophile monarchy, Catholic at first, then only nominally Orthodox, led to the church being pushed to the periphery of national life, except where it could be exploited to serve nationalist interests, as in Macedonia. After the First World War the church set about systematically renewing its structures, training a better quality of clergy, for instance, but it was not able to reclaim the ground it had lost.

3 Spas Raikin, Open Letter to Dr Zhelyu Zhelev, President of Bulgaria, 6 August 1992, English translation, pp. 6-9.

4 Spas Raikin, 'Schism in the Bulgarian Orthodox Church', Alive in Christ, vol. VIII, no. 3, winter 1992, pp. 46-9.

5 Information supplied by intellectuals in Veliko Turnovo, October 1990.

6 Information on infiltration methods supplied by an elderly lady and a teacher at the Academy.

7 Keston News Service (KNS), no. 323 (13 April 1989), pp. 15-16.

8 'Bulgaria. The second and fourth estates after communism. Chronicle of a schism', East European Reporter, vol. 5, no. 5, September-October 1992, p. 19. Raikin, 'Schism...' p. 47.

9 KNS, no. 325 (11 May 1989), pp. 13-14.

${ }^{10} K N S$, no. 338 (16 November 1989), p. 13; no. 340 (14 December 1989), pp. 3-4.

$11 K N S$, no. 342 (25 January 1990), p. 18; Simon Simonov, 'Church-state relations after Zhivkov's fall', RFE Report on Eastern Europe, vol. 1, no. 17 (17 April 1990), pp. 6-7.

$12 K N S$, no. 353 (28 June 1990), p. 10.

$13 K N S$, no. 352 (14 June 1990), p. 10.

${ }_{14} K N S$, no. 355 (26 July 1990$)$, pp. 5-6.

$15 K N S$, no. 362 (8 November 1990), pp. 9-10.

16 KNS, no. 349 (3 May 1990), p. 10.

$17 K N S$, no. 366 (10 January 1991), p. 4.

18 Barbara Baker, 'Bulgarian church wrestles with past, seeks a new purity', News Network International - World Watch (5 September 1991), pp. 9-16.

19 Article in Otechestvo, no. 3 (1990). See Simonov, op. cit., pp. 7-8.

${ }^{20} K N S$, no. 356 (9 August 1990), p. 9; no. 358 (13 September 1990), pp. 4-5.

${ }^{21}$ Interview 'Beshe chudo nevizhdano - Sinodut se klanyashe pred oltara na ateizma' Demokratsiya (Union of Democratic Forces) (22 March 1991). 
22 KNS, no. 376 (30 May 1991), p. 14.

${ }^{23}$ Mitko Lachev, 'Kak Svetiyat Sinod razpredelya chuzhdestrannite pomoshti: Evangelskata pritcha za dvete rizi v bulgarski variant', Demokratsiya (16 March 1991).

24 Rada Nikolaev, 'The new non-communist government', RFE Report on Eastern Europe, vol. 2, no. 47 (22 November 1991), p. 1.

25 In conversation with the author in October 1992, Spas Raikin described the schism as 'chantage'.

${ }^{26}$ Kjell Engelbrekt, 'Bulgaria's religious institutions under fire', $R F E / R L$ Research Report, vol. 1, no. 38 (25 September 1992), p. 62.

27 Raikin, Open Letter, p. 4.

28 'Filip Dimitrov opposes state intervention in religious affairs', Summary of World Broadcasts (SWB) (BBC, Caversham) (15 May 1992).

29 'Zhelev briefed on split in Bulgarian Orthodox church leadership', $S W B$ (21 May 1992).

${ }^{30}$ Raikin, Open Letter, pp. 4, 5, 6; Raikin, 'Schism. . ', pp. 46-7.

31 'Serious rift in Orthodox Church: accusations of state interference', $S W B$ (5 June 1992). Religious teaching in schools had still not been made legal by October, although in practice recognised teachers of religion had access to some schools. In a conversation with the author, Subev blamed Nikolai Vasilev, the Minister for Education, for the delay.

32 'Keep it legal: interview with Metodi Spasov', East European Reporter, vol. 5, no. 5, September-October 1992, p. 20. See also note 31. For Neofit's defence, see E. Konstantinova, 'Unholy row splits Bulgaria's church', Independent (London) (28 December 1992).

33 Raikin, Open Letter, pp. 11-16.

34 Information from Archimandrite Evlogi, rector of Plovdiv seminary, October 1992.

35 'Constitutional court rules against state interfering in church dispute', $S W B$ (11 June 1992).

${ }^{36}$ Raikin, Open Letter, p. 5.

${ }^{37}$ Raikin, 'Schism...', p. 47.

38 Information to the author from a teacher and two theological students, interviewed in the cathedral, October 1992. See also 'Human chain hinders Patriarch from entering Sofia', $S W B$ (4 July 1992).

39 'Bulgaria. The second and fourth estates...', p. 19; Raikin, 'Schism...', p. 47.

40 'Orthodox leaders press Dimitrov to settle church schism', SWB (24 August 1992).

41 Interview with Bishop Neofit, October 1992.

42 'Premier Dimitrov meets priests to discuss Bulgarian Orthodox church conflict', $S W B$ (3 September 1992).

43 Raikin, Open Letter, p. 4.

44 Raikin (an eye-witness), 'Schism...', pp. 47-8.

${ }^{45}$ Information direct from interview with Subev; also Raikin, 'Schism...', p. 48.

46 Interview with author.

${ }^{47}$ In particular, Subev called on Tsar Simeon II to return from Spain at a time when the President was abroad. See 'Bulgaria. The second and fourth estates...', p. 20.

48 Though remaining in the UDF, Subev had switched his support to the BSP candidate, Petur Boyadzhev, who had been a fellow dissident although unsympathetic to the MRF. Boyadzhev's candidature was, however, withdrawn becuse of a scandal: the French police were interested in him.

${ }^{49}$ Kjell Engelbrekt, 'Technocrats dominate new Bulgarian government', $R F E / R L$ Research Report, vol. 2, no. 4 (22 January 1993), p. 2.

so Almost all the information in this section is supplied by a reliable source who prefers to remain anonymous.

51 Raikin, Open Letter, p. 15.

52 'Istinata za dukhovniya sud nad komunizma' Demokratsiya, 29 January 1993.

53 Milcho Spasov, 'Tryabva li sega da izirame patriarkh?' Demokratsiya, 5 February 1993. 